$\begin{array}{r}\text { Volume and Issues Obtainable at Center for Sustainability Research and Consultancy } \\ \text { Journal of Business and Social Review in Emerging Economies } \\ \text { ISSN: 2519-089X (E): 2519-0326 } \\ \text { Volume 6: No. 4, December } 2020 \\ \text { JSRC } \\ \text { Journal homepage: www.publishing.globalcsrc.org/jbsee } \\ \hline\end{array}$

\title{
Measuring Pakistan's Legislative Preparedness against COVID-19: A Critical Study of Newly Promulgated Law
}

\author{
1 Jibran Jamshed, ${ }^{2}$ Ammara Mujtaba, ${ }^{3}$ Muhammad Waqas Javed, ${ }^{4}$ Syed Wajdan Rafay Bukhari \\ ${ }^{1}$ Assistant Professor, Department of Law, Islamia University of Bahawalpur, Pakistan \\ jibran_jamshed@yahoo.com \\ ${ }^{2}$ Lecturer, Bahria University Islamabad, Pakistan, ammara_mujtaba@yahoo.com \\ ${ }^{3}$ Lecturer, School of Law, Quaid-i-Azam University, Islamabad, Pakistan, mwjaved@qau.edu.pk \\ ${ }^{4}$ Lecturer, University Law College, University of Sargodha, Pakistan, wajdan.rafay@uos.edu.pk
}

\begin{tabular}{l}
\hline ARTICLE DETAILS \\
\hline History \\
Revised format: November \\
2020 \\
Available Online: December \\
2020 \\
\hline Keywords \\
Legislative Preparedness, \\
COVID-19, Promulgated Law, \\
Pakistan
\end{tabular}

JEL Classification

M10, M12

\begin{abstract}
Background: Since December 2019, the COVID-19 pandemic has challenged the international community on health and legislative fronts. The widespread disease needs an effective response from the health-care system as well as the legislative framework. Pakistan is facing a challenge from the underdeveloped health-care system as well as a lack of awareness about the available laws to deal with the issue. Awareness about the relevant laws is a precursor to the establishment of rule of law. This study will doctrinally analyse the national laws of Pakistan to make the response more effective. The awareness about the relevant laws will supplement the healthcare response against the pandemic of COVID-19. Since Pakistan is a federation and healthcare is a provincial subject, therefore the study limits itself to the laws of Punjab, the largest populated province of Pakistan. Objectives: This study will analyse the available healthcare laws to deal with the recent outbreak of COVID-19. The focus will remain on the doctrinal measurement of the effectiveness of The Punjab Infectious Diseases (Prevention and Control) Act 2020 (PIDA) vis-à-vis already existing laws. It will also highlight the salient features of the PIDA 2020 along with its effectiveness to deal with the current pandemic. Method: The study benefits from documentary analysis of legal documents. The method is nearer to the doctrinal research method in law. The study will shape itself into two parts. First will be lax lata that will ascertain what is the relevant healthcare law to deal with infectious diseases like COVID-19. The next step will be lax ferenda where the study will propose how it can become more effective to deal with the issue. The research will opt black letter approach. Conclusion: This study finds that the adoption of PIDA 2020 is in spirit with dealing with the pandemic of the COID-19. The law has shown positive trends in protecting the population from the widespread impact of the diseases. The World Health Organization has
\end{abstract}


appreciated Pakistan's methods and strategies against the first wave of the COVID-19 with reference to response in Punjab, the largest province of Pakistan..

(C) 2020 Center for Sustainability Research and Consultancy Pakistan under a Creative Commons Attribution-NonCommercial-ShareAlike

4.0

Corresponding author's email address: jibran_jamshed@yahoo.com

Recommended citation: Jamshed, J., Mujtaba, A., Javed, M. W., \& Bukhari, S. W. R. (2020). Measuring Pakistan's Legislative Preparedness against COVID-19: A Critical Study of Newly Promulgated Law. Journal of Business and Social Review in Emerging Economies, 6(4), 1517-1524

\section{Introduction}

The outbreak of the COVID-19 pandemic has been an unprecedented challenge for the global economy, health, and rule of law. On 30 January 2020, The World Health Organization (WHO) declared the COVID-19 outbreak as "Sixth Public Health Emergency Services (SPHEC)"(Bilgin et al., 2020). The deadly disease originated from Mainland China after the report of the first cases from Wuhan City of China in Hubei Province in December 2019. The disease was named as Severe Acute respiratory syndrome coronavirus 2 (SAR-Co V-2) for the reason of leading to severe respiratory infections and pneumonia (She J. et al., 2020). The root of the infection is often argued; however, it is believed to start from the local seafood market in Wuhan and it got transmitted to the visitors. This initial endemic turned into a global pandemic in a very short period (Zu ZY et al., 2019; Millan, 2020).

The COVID-19 which is more commonly known as Coronavirus spread at a rapid pace all over the world from China. This new virus is related to Severe Acute Respiratory Syndrome (SARS) and Middle East Respiratory Syndrome (MERS). The severity and effects of this deadly virus are varying and different in each country and each region (Tang, 2000). It is also interesting to note that this is not the first outbreak of Coronavirus. SARS-Co V (Severe Acute Respiratory Syndrome Coronavirus) and MERS-Co V) Middle East Respiratory Syndrome Coronavirus outbreak was the previous coronavirus outbreaks (Zhou, 2020).

On 26 February 2020, the first case of COVID-19 has been confirmed by the Government of Pakistan in Provincial Capital Province Sindh i.e. Karachi. On the same day, another case was confirmed in Islamabad, Federal Capital, by the Federal Ministry of Health (Ali et al., 2020). Within 15 days, after the first case was confirmed, Coronavirus spread rapidly, and the total number of COVID-19 cases reached 20 in different parts of the country. All the reported cases have travel histories from Iran, Syria, and the UK (Waris et al., 2020). On 12 February 2020, the National Action Plan for Preparedness \& Response to Corona Virus Disease Pakistan was presented by the Ministry of National Health Services. The aim was to control the spread of disease and strengthen the Pakistan and its society for effective and swift response against COVID-19 (Waris et al., 2020).

Apart from preventive measures and scientific research, the states have started taking legislative measures to curtail the spread of the deadly virus. Effective legislation and its implementation have been significant for the containment of COVID-19. Many developing countries have outdated laws regarding infectious diseases before the advent of COVID-19. To beef up its response against the outbreak, Punjab and other provinces of Pakistan have introduced laws to stop the mass outspread of the virus.

\section{Methodology}

As mentioned in the summary above, the study benefits from documentary analysis techniques. The legal issues need analysis vis-à-vis primary and secondary sources of laws. While primary sources with context to Pakistan, a Common Law country, are legislations and case laws. For these reasons, the 
fundamental primary sources or documents remain legislations such as The Punjab Epidemic Diseases Act 1958 (PEDA 1958), Pakistan Penal Code 1860 (PPC 1860), The Punjab Infections Diseases (Prevention and Control) Ordinance 2020 (PIDA 2020). The secondary sources used are books, research articles, and data published by the Government and Non-Government Organization.

As the documentary analysis technique is close to doctrinal research methods in legal research, where a researcher examines an issue based on already existing doctrine, the study uses black-letter approach. The study will be desk-based to analyse the effectiveness of laws dealing with infectious diseases including the outbreak of the COVID-19, the effectiveness of laws, and what can be possibly done to make them more effective.

\section{Objectives of the Study}

The followings are the main objectives this study aims to achieve.

1- Awareness of the law is significant for creating the rule of law in society. Therefore, this study will create awareness about the legal framework in Punjab, Pakistan to control the infectious disease with special reference to the COVID-19.

2- To critically examine and analyze the effectiveness of the Punjab Infectious Diseases (Prevention and Control) Act 2020 which deals with COVID-19 and other infectious diseases in the Province of Punjab

3- To compare this new law with the previous legislation dealing with COVID-19

4- To suggest how to enforce the laws effectively.

\section{Background}

Almost half of the population of Pakistan resides in Punjab, a densely populated province of Pakistan (Pakistan Bureau of Statistics, 2020). The COVID-19 has challenged the government of Punjab at economic, healthcare, and administrative levels. With the highest population density in Pakistan, the possibility of a larger impact o the COVID-19 was on the cards. To deal with the issue, there was an urgent need to promulgate a new and effective law to curtail the outspread of the COVID-19. Before the spread of COVID-19, The Punjab Epidemic Diseases Act 1958 primarily dealt with the control of infectious diseases including the COVID-19. Being an outdated law, it was not effective and hence Government of Punjab decided to repeal that law and promulgated The Punjab Infectious Diseases (Prevention and Control) Ordinance 2020 to deal with modern challenges posed by the COVID-19. On 11 August 2020, the provincial assembly adopted the Punjab Infectious Diseases (Prevention and Control) Act 2020 (PIDA 2020).

To build the context, this study will explore the limitations of the repealed Punjab Epidemic Diseases Act 1958.

\subsection{The Framework of the Punjab Epidemic Diseases Act of 1958 (PEDA 1958)}

The legislative framework for controlling infectious diseases was adopted during the year 1958. The law provided the government to take certain measures to stop the spread of infectious diseases. In this regard, PEDA 1958 aimed to consolidate the laws relating to the prevention of the spread of dangerous epidemic diseases in Punjab Province as provided in the preamble of PEDA 1958. Section 2 of the act empowered the government, if threatened with outbreak of any dangerous epidemic disease, it may to adopt "measures and by public notice prescribe such temporary regulations to be observed by the public or any person or class of persons as it shall deem necessary to prevent the outbreak of such disease or the spread" (S.2, PEDA 1958).

This law empowered the Provincial Government to take all necessary steps when there is a danger of an epidemic disease outbreak. According to that law, the Provincial Government is empowered to inspect any person who is suspected of being infected with any such disease and the person can also be segregated in any hospital temporarily. The District Coordination Officer (DCO) was given power by this act to exercise all powers on behalf of the Provincial Government. Although it was also clarified that all such powers delegated by the Provincial Government shall be subject to such restriction, 
limitations, and conditions, as specified by the Provincial Government spread (S.2, PEDA 1958). According to section 3 of the PED Act 1958, "any person disobeying any regulation or order made under this act shall be deemed to have committed an offense punishable under section 188 of the Pakistan Penal Code". Section 188 of the Pakistan Penal Code describes the punishment for disobedience to order duly promulgated by a public servant. anyone who violates the section 188 of Pakistan Penal Code, "be punished with simple imprisonment for a term which may extend to one month or with a fine which may extend to six hundred rupees, or with both: and if any such disobedience causes or tends to cause danger to human life, health or safety or causes or tends to cause a riot or affray, shall be punished with imprisonment of either description for a term which may extend to six months, or with fine which may extend to three thousand rupees or with both" (S.188, PPC 1860).

PEDA 1958 was brief legislation that contains only 4 sections and it was not ready to deal with the multi-facet challenges posed by the COVID-19. It only contains general provisions regarding the powers of the provincial government to take some actions against the spread of infectious disease. There were no details, specifications, procedures, and specialized bodies provided in that act to deal with serious threats like COVID-19. The Act provides insignificant punishment for those who violate it hence fail to create effective deterrence. It was not capable to deal effectively with the infections diseased like COVID-19 and that is the reason it was repealed by the Punjab Infectious Diseases (Prevention and Control) Act 2020.

\subsection{The Domain and Scope of Punjab Infectious Diseases (Prevention and Control) Act 2020}

To deal with the outbreak of the COVID-19 effectively, PIDA 2020 was promulgated on $27^{\text {th }}$ March 2020. According to the preamble of PIDA 2020, the law is passed to provide for the prevention and control of infectious diseases in the Punjab and matters related to it. Although the COVID-19 is not mentioned anywhere in the preamble or the Ordinance, yet it was promulgated to control specifically the spread of Coronavirus in Punjab.

In the beginning, this law defines some important designations like Potentially Infectious Person, Director General Health, Secretary, and Notified Medical Officer. According to section 2 (g) of PIDA 2020, the "Potentially Infectious Person" as a "person who is suspected to be infected or contaminated with an infectious disease; or is a risk that such person might spread, infect or contaminate other persons with an infectious disease; or has arrived from or through an area affected by an infectious disease within fourteen days or such other period as may be specified by the secretary immediately preceding the date of his arrival". The period of 14 days is specifically mentioned in this definition which makes it clear that the immediate concern of this law is to combat COVID-19.

In this law, the secretary and Director General Health are given special roles with specific powers. The Director-General Health is the Director General Health Services, Punjab (S.2b, PEDA 2020), and Secretary is defined as Secretary to the Government, Primary and Secondary Healthcare Department (S.2j, PEDA 2020). Notified Medical Officer is a medical officer notified for this Act by the Secretary (S.2j, PEDA 2020). In simple words, he is the Doctor who will have very important duties and powers in relation to this Law. According to 3(a) of PEDA 2020, "The Secretary may with the approval of Chief Minister, by notification in the Official Gazette, declare that the incidence of transmission of infectious diseases poses a serious and imminent threat to public health in the whole or any part of Punjab". The same section also provides that the secretary after approval of the Chief Minister can revoke a declaration made by him. It also binds the secretary to get advice from Director General Health regarding the declaration or revocation of Disease along with at least two eminent epidemiologists appointed by the Chief Minister. Under this, the secretary is empowered to impose a duty upon all registered medical practitioners in Punjab to treat cases of infection or contamination. it means the Government can impose duties in case of infection emergency on any doctor/medical practitioner weather Private or Government. Similarly, the Secretary is empowered to declare any medical facility in Punjab to be a treatment center for specific infectious diseases whether private or government. "A 
registered medical practitioner shall include a registered medical practitioner, not in employment of Government, and the term health facility shall be deemed to include a clinic, hospital, diagnostic laboratory, and any other facility engaged in the provision of health services and not owned, financed, managed or run by the Government" (S.4, PEDA 2020). Section 7 of PIDA 2020, empowers the Director-General Health to "issue direction prohibiting or imposing one or more requirements or restrictions in relation to the holding of an event or gathering for a specific period". Director-General Health can restrict the specific gathering or event concerning the number of people etc. He can impose these restrictions on the owner or occupier of premises for an event, organizers of the event, or another person who is holding such an event.

Section 8 of PIDA 2020 stated that The Director General is also empowered "to issue directions prohibiting or imposing one of more requirements or restrictions in relation to the entry into, exit from or location of persons in premises for specific period". This power is given to the DG Health in order to contain the infection if it has already spread into specific areas. A specific place can be sealed and its entry and exit points are restricted for a specific period. Similarly, Deputy Commissioner of the concerned area may on the advice of the secretary, issue directions prohibiting or imposing requirements or restriction in relation to the entry into, exit from, or location of the person, goods, vehicles, vessels, and other means of transportation in any area for a specific period. It is important to note that Smart Lockdowns by the Government of Pakistan during the COVID-19 pandemic are imposed under the above-mentioned sections. This ordinance makes it obligatory for the potentially infectious person to move and remain in a specific place for a specific time. According to the Act, "A notified medical officer may, after having informed the potentially infectious person of the reasons for doing so, direct such person to proceed to a specified place that is suitable for screening and assessment and remains there for a specific period". If a potential infection person refuses to follow the advice of a Medical officer, the person can be moved to that specific place by the Police through the concerned Head of the District Police Officer. He can be moved to that specific place for forty-eight hours for screening and assessment in normal circumstances. A notified Medical officer may "impose upon a potential infectious person one or more screening requirements to assess the level of risk of infection or contaminating to others and carry out such assessment". According to section 11 of PIDA, "the potentially infectious person is bound to answer every question related to his health and travel history. He is also bound to produce any document with may be required in assessing his health, to allow personal examination like measurement of body temperature and other physical conditions, and to give biological sample by an appropriate mean".

The Notified Medical Officer plays a key role in this law. He is entrusted with many important duties and given many powers to fulfill his duties effectively. According to section 12 of PIDA 2020, Where after the screening and assessment, the potentially infectious person found to be infected or contaminated, the notified Medical Officer may require such a person.

- To undertake further screening and assessment

- Be retained at a specific place for a specific period

- Be retained at a specific place in isolation

- Restrict his movements or travel including travels within and inside Province

- Restrict his activities including work or business

- Restrict his contact with other persons

This section provides the period of restriction up to 14 days under normal circumstances. The medical officer can direct the Police Officer to enforce the directions.

Although notified Medical Officer has given many powers under this law yet there are some restrictions, pre-conditions, and manners provided in this law for the exercise of this power by the notified Medical Officers and Police Officers. According to section 14 of PIDA 2020, "It is the duty of every person who knows or believes or has reason to know or believe, that a person under his care, supervision, or control 
is suffering from an infectious disease or is contaminated, to report such case to the notified medical officer immediately". Hence this law made it compulsory for all residents of Punjab Province to provide information to the Government regarding any person who might be infected so that authorities can make proper arrangements for the containment of infection.

According to section 17 of the Act, "a person commits an offense if he fails without reasonable excuse to comply with any direction, reasonable instruction, duty, requirement, or restriction imposed upon him under the Ordinance". The punishment provided is, "A first-time offender shall, under this section, be punished with imprisonment for a term not exceeding two months or a fine not exceeding fifty thousand rupees or both. If a person is guilty of a repeat offense under this section, he can be punished with imprisonment for a term not exceeding six months or a fine not exceeding one hundred thousand rupees or both".

This Ordinance also differentiates between the offense committed by an individual and a body corporate. Where an offense under this section is committed by a body corporate, the fine for the first offense shall not be less than fifty thousand rupees and not exceeding two hundred thousand rupees, and the fine for a repeat offense shall be between one hundred thousand rupees (minimum) and three hundred thousand rupees (maximum). There is a difference between the fine imposed on individuals and body corporate. There are more strict punishments for those who violate certain sections of this Ordinance. If a potentially infectious person fails to comply with the duties imposed on him by Medical Officer or provides false information to the medical officer or obstructs a person who is exercising the powers conferred on him under this law than he is liable for strict punishments. According to section 18, "a person guilty of first offence be punished with imprisonment for a term not exceeding three months or a fine not exceeding fifty thousand rupees or both, and a person guilty of a repeat offence be punished with imprisonment for a term not exceeding one year or fine not exceeding one hundred thousand rupees or both. The offence for running away from a place of retention has more serious consequences. Under this law, if a person runs away or attempts to run away while being moved to or kept at a place under this law, the first offence is punished with imprisonment for a term not exceeding six months or a fine not exceeding fifty thousand rupees or both, repeat offence be punished with imprisonment for a term not exceeding six months or a fine not exceeding fifty thousand rupees or both".

This comprehensive punishment provided in this law is one of its many positive aspects. The minimum and maximum amount of fine are also provided in this law for different offences which means even a court cannot impose any other amount of fine outside these limits. The limitation on the discretion of the court is according to the modern standard of punishments and it not only curtails the arbitrary powers of courts but also minimize the misuse of this law. A Magistrate of first-class is empowered to take cognizance of or try an offence under this Ordinance. All the offences under this law shall be tried in court in summary trials as provided in the Code of Criminal Procedure 1898. The Summary Procedure provided in this Law for the offences makes it sure that courts can decide the matters in time.

\subsection{Synergizing the PIDA 2020 by the Pakistan Penal Code 1860 regarding the Infectious Diseases}

The laws dealing with the control of infectious diseases can be synergized by the relevant provisions in the PPC 1860, federal legislation. The code is a substantive criminal law containing offences and their punishments. Being a federal law, it is also enforceable in the Province of Punjab like all other provinces of Pakistan. It contained some provisions which are related to the prevention of infectious diseases and provide punishments for those who violate. For instance, the section 269 of PPC provides "that whoever unlawfully or negligently does any act which is, and which he knows or has reason to believe to be, likely to spread the infection of any disease dangerous to life, shall be punished with imprisonment of either description for a term which may extend to six months or with fine or with both". Section 270 of PPC is about "the malignant act likely to spread infection of disease dangerous to life. Whoever malignantly does any act which is, and which he knows or has reason to believe to be, likely to spread the infection of any disease dangerous to life, shall be punished with imprisonment of either description 
for a term which may extend to two years or with fine or with both". In the next section i.e. 271 of PPC, it is provided that, "whoever knowingly disobeys any rule made and promulgated by the Federal or any Provincial Government for putting any vessel into a state of quarantine or for regulating the intercourse of vessels in a state of quarantine with the shore or with other vessels, or for regulating the intercourse between places where an infectious disease prevails and other places, shall be punished with imprisonment of either description for a term which may extend to six months or with fine or with both". Although these sections provide punishment for those who violate the law by spreading infectious diseases, yet the punishments provided in these sections are not strict enough to create any strong deterrence. These sections are not repealed and still part of the PPC, but they are seldom used practically. Dealing with the control of the outbreak of COVID-19 under the criminal laws, in Punjab, can positively help in effectively controlling the contact of the affected person with the population. In the most populated province of Pakistan, the adoption of new laws and effective enforcement mechanism has played a positive role in curtailing the gatherings those may lead to a widespread outbreak of the virus in the society.

\section{Discussion \& Analysis}

The legislative measures taken by the Government of Punjab has been effective in controlling the spread of the virus by authorizing the local authorities to stop all sort of public gatherings. Moreover, these laws further empower the authorities to take all necessary actions in relation to the protection of healthcare. However, these legislative measures have attracted criticism form economic and human rights perspectives. The PIDA 2020 empowers the local authorities to control all economic and mobilization restrictions that may affect the fundamental rights of the citizens. There are some strong arguments against the lockdowns and economic shutdown in a developing country like Pakistan where economic indicators are already down. But the policy choice for Government is the same as it is around the world for most of the Governments i.e. simple trade-off between saving lives and saving the economy.

During the pandemic, the government authorities are facing the issue to balance strict control measures and protection of economic activities as well as human rights. The choice has always been the protection of life by imposing strict social distancing laws and shut down the economic activities although the severity and magnitude of these shutdowns vary from country to country. In Pakistan, the government imposed the strict lockdown during March 2020, but later switched to the smart lockdown and resumed the economic activities. The application of PIDA 2020 has been effective in controlling the spread of the virus. A recent study on the Scandinavian countries suggests that most of the economic contraction is caused by the virus itself and occurs regardless of the social distancing laws (Sheridan et al., 2020). This study also suggests that the social distancing laws, which empower the Governments to impose lockdowns and shut down economic activities, are often considered contrary to the economy and human rights. However, these measures are necessary to save lives, a basic human right. In such circumstances the newly promulgated PIDA 2020 is justifiable and it already has shown the positive results because the number of infections in Punjab reduced dramatically after its implementation.

\section{Conclusion}

The study has tried to achieve the goals of awareness and analysis of local laws dealing with the control of the infectious disease. The study explains and interprets the newly promulgated Punjab Infectious Diseases (Prevention and Control) Act 2020. The legislation has been useful in introducing an effective substantive law that enjoys an advanced enforcement mechanism. The law has been useful in controlling the spread of the virus in Punjab by restricting public gathering. Former laws controlling the infectious diseases did not give authorities space to deal with the novel challenges posed by the COVID-19. Since the legislation is new, therefore, the study examines the salient features and important characteristics of the PIDA 2020 to create awareness about the law, an essential part of establishing rule of law in society. The study finds that the adoption of the PIDA 2020 has balanced the legislative, enforcement, and policymaking of Punjab government with the protection of related human rights. A further study may investigate the issue using the qualitative research methods by conducting the interviews of relevant 
stakeholders such as enforcement agencies, district administration, market (traders) unions, and public

\section{References}

Ali, I., Shah, S. A., \& Siddiqui, N. (2020). Pakistan confirms first two cases of coronavirus, govt says "no need to panic". DAWN. COM, February, 26.

Bilgin, S., Kurtkulagi, O., Kahveci, G. B., Duman, T. T., \& Tel, B. M. A. (2020). Millennium pandemic: a review of coronavirus disease (COVID-19). Experimental Biomedical Research, 3(2), 117-125.

COVID-19 live dashboard (Pakistan): national institute of health Islamabad. https://www.nih.org.pk/novel-coranavirus-2019-ncov/. Accessed 5th April 2020.

Deng S-Q, Peng H-J. Characteristics of and public health responses to the Coronavirus disease 2019 outbreak in China. J Clin Med. 2020;9(2):575.

Gostin, Lawrence O., Eric A. Friedman, and Sarah A. Wetter. "Responding to COVID-19: How to Navigate a Public Health Emergency Legally and Ethically." Hastings Center Report 50, no. 2 (2020): 8-12.

Millán-Oñate, J., Rodriguez-Morales, A. J., Camacho-Moreno, G., Mendoza-Ramírez, H., RodríguezSabogal, I. A., \& Álvarez-Moreno, C. (2020). A new emerging zoonotic virus of concern: the 2019 novel Coronavirus (SARS CoV-2). Infectio, 24(3), 187-192.

Pakistan Bureau of Statistics, https://web.archive.org/web/20171015113737/http://www.pbscensus.gov.pk/

Punjab Epidemic Diseases Act 1958

Pakistan Penal Code 1860

Punjab Infectious Diseases (Prevention and Control) Ordinance 2020

She, J., Jiang, J., Ye, L., Hu, L., Bai, C., \& Song, Y. (2020). 2019 novel coronavirus of pneumonia in Wuhan, China: emerging attack and management strategies. Clinical and translational medicine, 9(1), 1-7.

Sheridan, A., Andersen, A. L., Hansen, E. T., \& Johannesen, N. (2020). Social distancing laws cause only small losses of economic activity during the COVID-19 pandemic in Scandinavia. Proceedings of the National Academy of Sciences, 117(34), 20468-20473.

Tang, H. March 2000. Winners and Losers of EU Integration, Policy Issues for Central and Eastern Europe.

Waris, A., Khan, A. U., Ali, M., Ali, A., \& Baset, A. (2020). COVID-19 outbreak: current scenario of Pakistan. New Microbes and New Infections, 100681.

Zu, Z. Y., Jiang, M. D., Xu, P. P., Chen, W., Ni, Q. Q., Lu, G. M., \& Zhang, L. J. (2020). Coronavirus disease 2019 (COVID-19): a perspective from China. Radiology, 200490.

Zhou, Peng, Xing-Lou Yang, Xian-Guang Wang, Ben Hu, Lei Zhang, Wei Zhang, Hao-Rui Si et al. "A pneumonia outbreak associated with a new coronavirus of probable bat origin." nature 579, no. 7798 (2020): 270-273. 